\title{
PENGARUH PENDEKATAN CONCRETE-PICTORIAL-ABSTRACT (CPA) TERHADAP KEMAMPUAN REPRESENTASI MATEMATIS PADA TOPIK TRIGONOMETRI
}

\author{
Radiusman*1, Maslina Simanjuntak $^{2}$ \\ ${ }^{1}$ Universitas Mataram, Nusa Tenggara Barat \\ ${ }^{2}$ Universitas Negeri Surabaya, Jawa timur \\ radius_saragih88@unram.ac.id*1, maslin.simanjuntak@gmail.com² \\ *Corresponding Author
}

Received 15 August 2020; revised 30 August 2020; accepted 01 October 2020.

\begin{abstract}
ABSTRAK
Penelitian kuantitatif ini bertujuan untuk melihat pengaruh pendekatan ConcretePictorial-Abstract (CPA) terhadap kemampuan representasi matematis siswa pada materi trigonometri. Representasi matematis merupakan dasar siswa untuk memahami dan menggunakan ide matematis. Populasi dari penelitian ini adalah seluruh siswa kelas X IPA MAN 2 Bekasi tahun ajaran 2019/2020. Sampel pada penelitian ini diambil menggunakan teknik kluster sampling dimana terdapat 40 siswa sebagai kelas eksperimen dan 40 orang sebagai kelas kontrol. Penelitian ini menggunakan desain pre-test-posttest control group design. Penelitian ini menggunakan bantuan Lembar Kerja Peserta Didik (LKPD) yang berisikan materi-materi singkat trigonometri, permasalahan trigonometri dan langkah-langkah penyelesaian permasalahan trigonometri. Berdasarkan hasil uji beda N-Gain ternormalisasi diperoleh bahwa nilai sig. hitung $(0,00)<$ nilai sig. tabel $(0,05)$. Berdasarkan hal tersebut dapat disimpulkan bahwa kemampuan representasi siswa yang menggunakan pendekatan CPA lebih baik dibandingkan siswa yang menerima pembelajaran secara konvensional. Pendekatan CPA juga memberikan pengaruh positif lain yaitu siswa terlatih untuk menguasai teknik penyelesaian permasalahan dibandingkan hanya sekedar mencari penyelesasian permasalahan trigonometri.
\end{abstract}

Kata kunci: pendekatan CPA, representasi matematis, trigonometri.

\begin{abstract}
This quantitative research aims to see the effect of the Concrete-Pictorial-Abstract (CPA) approach on students' mathematical representation abilities in trigonometry. Mathematical representation is basic for students to understand and use mathematical ideas.The population of this study was all students of class X IPA MAN 2 Bekasi in the academic year 2019/2020. The sample in this study was taken using the cluster sampling technique where there were 40 students
\end{abstract}


as the experimental class and 40 students as the control class. This study used a pretest-postes control group design. This study uses the help of student worksheets (LKPD) which contains brief trigonometry materials, trigonometry problems, and steps to solve trigonometry problems. Based on the t-test results of the normalized $\mathrm{N}$-Gain value, it is found that the value the sig. count $(0,00)$ $<$ sig. Table $(0,05)$. Based on this, it can be concluded that the representation ability of students who use the CPA approach is better than students who receive conventional learning. The CPA approach also has another positive effect, namely that students are trained to master problemsolving techniques rather than just looking for solving trigonometry problems.

Keywords: CPA approach, mathematics representation, trigonometry.

\section{PENDAHULUAN}

Representasi merupakan salah satu kemampuan yang harus dikuasai dalam pembelajaran matematika. Representasi matematis diartikan sebagai hubungan antara objek dan simbol matematika. Representasi juga dapat diartikan sebagai prosen melambangkan suatu objek (Rosengrant, Etkina, \& Van Heuvelen, 2007). Objek dalam matematika dapat disimbolkan dalam bentuk kata, diagram, grafik dan simbol (Sahendra, Budiarto, \& Fuad, 2018). Kemampuan representasi matematika membantu siswa dalam mengembangkan, memperdalam pemahaman serta mengkomunikasikan pemikiran terhadap konsep matematika (NCTM, 2000). Kemampuan representasi matematika sudah dimulai pada masa anak-anak mulai belajar berhitung. Anak-anak menggunakan simbol-simbol eksternal dalam merepresentasikan angka (Batchelor, Keeble, \& Gilmore, 2015).

Kemampuan representasi juga digunakan sebagai cara mengungkapkan ide dan memahami penggunaan ide matematis (Astuti, 2017). Siswa dapat menggunakan kemampuan representasi matematis menggunakan area model dalam memahami pecahan (Wahyu, Amin, \& Lukito, 2017). Kemampuan representasi memiliki beberapa manfaat antara lain: memberitahukan kepada guru tentang bagaimana siswa berpikir tentang permasalahan konteks matematika, memberikan informasi tentang bagaiman siswa memecahkan peramasalahan matematika (Kalathil \& Sherin, 2000), serta memberikan informasi tentang kemampuan siswa menyelesaikan permasalahan kontekstual (Dewolf, Van Dooren, \& Verschaffel, 2017), misalnya permasalahan dalam trigonometri (Mesa \& Herbst, 2011). 
Trigonometri merupakan salah satu materi yang harus dipahami dan tidak terpisahkan oleh siswa sekolah mengengah atas. Triginometri memiliki hubungan yang sangat erat dengan aljabar, geometri, dan fungsi (Price \& Van Jaarsveld, 2017; Solikin, 2016). Salah satu kompetensi yang harus dikuasai siswa dalam materi trigonometri adalah menghubungkan dan memecahkan masalah kontekstual yang berkaitan dengan rasio trigonometri dalam segitiga siku-siku (Dündar, 2015; Sarkam, Sujadi, \& Subanti, 2019) serta konsep geometri (Brijlall \& Niranjan, 2015), namun pada kenyataannya trigonometri merupakan salah satu mata pelajaran sulit untuk dipahami dalam matematika sekolah menengah dan tidak disukai oleh kebanyakan siswa (Gerhana, Mardiyana, \& Pramudya, 2017; Kamber \& Takaci, 2018).

Pemahaman terhadap konsep trigonometri hanya mampu dikuasai oleh siswa yang memiliki prestasi tinggi sedangkan siswa yang memiliki prestasi rendah hanya mengganggap trigonometri sebagai materi yang abstrak (Gür, 2009; Walsh, Fitzmaurice, \& O’Donoghue, 2017). Kelemahan siswa dalam memahami konsep trigonometri juga dilatarbelakangi oleh lemahnya konsep geometris. Hal ini disebabkan karena siswa perlu menghubungkan dan mengidentifikasi pengukuran dalam bentuk gambar dan rasio numerik (Maor, 2013). Kendala lain yang dihadapi siswa dalam memahami permasalahan trigonometri, antara lain: banyak tidak mampu untuk menerapkan trigonometri dalam menyelesaikan masalah kontekstual seperti menggunakan sifat komutatif dan distributif (Price \& Van Jaarsveld, 2017) serta mengembangkan konsep geometri dalam menyelesaikan permasalahan (Sarkam et al., 2019).

Permasalahan serupa juga ditermukan oleh peneliti di kelas X MAN 2 Bekasi. Berdasarkan hasil wawancara diperoleh fakta bahwa kesulitan terhadap materi trigonometri dipengaruhi beberapa faktor, antara lain: pemahaman siswa terhadap simbol, pemahaman terhadap perbandingan trigonometri dalam segitiga siku-siku, menentukan konsep yang akan digunakan, serta menerapkan perbandingan segitiga siku-siku dalam permasalahan kontekstual. Selain itu kebanyakan siswa mengganggap trigonometri merupakan sesuatu yang abstrak sehingga sulit untuk dipahami. Fakta rendahnya kemampuan representasi matematis siswa terhadap materi juga diperkuat dengan hasil pretest yang diujikan 
kepada siswa. Berdasarkan hasil wawancara dan pretest tersebut maka diperlukan suatu pendekatan baru yang tepat untuk mengajarkan materi trigonometri. Salah satu pendekatan yang dapat digunakan dalam menyelesaikan permasalahan trigonometri adalah pendekatan Concrete-Pictorial-Abstract (CPA).

Pendekatan CPA merupakan suatu instruksi bertahap yang menggerakkan siswa untuk memecahkan permasalahan matematika dengan memanipulasi benda yang konkret untuk menyelesaikan masalah dalam bentuk gambar atau representasi (Bouck, Park, \& Nickell, 2017). Pendekatan CPA terdiri dari tiga tahap yaitu concrete (pembelajaran menggunakan benda nyata), pictorial (pembelajaran menggunakan media gambar) dan abstract (pembelajaran melalui sesuatu yang sudah abstrak) (Mahayukti, Dianawati, Ardana, \& Suryawan, 2019). Pada tahap concrete siswa memanipulasi benda nyata seperti spidol, alat ukur, dan objek lain yang dapat digunakan siswa selama kegiatan pembelajaran, selanjutnya pada tahap pictorical siswa menggunakan representasi berupa gambar, diagram, grafik yang akan digunakan untuk menafsirkan permasalahan matematika, dan pada tahap abstract siswa diminta untuk menulisikan representasi simbol yang menunjukkan pemahaman siswa terhadap permasalahan matemtika tersebut (Sousa, 2008). Pendekatan CPA dimulai ketika guru mengajarkan siswa untuk memanipulasi benda konkret untuk memecahkan permasalahan matematika dengan cara melakukan demonstrasi permasalahan yang diberikan. kemudian guru membimbing siswa untuk menggambarkan objek dengan cara memberikan petunjuk dan isyarat sesuai dengan kebutuhan dan diakhiri dengan siswa memecahkan masalah tanpa mendapat dukungan dari guru (Agrawal \& Morin, 2016; Whitin, 2007). Alur pendekatan CPA dapat dilihat pada Gambar 1.

- Siswa memanipulasi benda nyata sebagai alat yang digunakan dalam pembelajaran

- Menggunakan representasi berupa gambar, tabel, diagram dalam menafsirkan permasalahan matematika

- Menuliskan representasi simbol yang menunjukkan pemahaman siswa terhadap permasalahan matematika

Gambar 1. Alur Pendekatan Concrete-Pictorial-Abstract (CPA) 
Berdasarkan tahapan pendekatan CPA tersebut, maka pendekatan ini sesuai untuk mengatasi permasalahan representasi siswa kelas X MAN 2 Bekasi pada materi trigonometri. Hal ini disebabkan karena pada tahapan CPA terdapat kegiatan memanipulasi atau mendemonstrasikan suatu kegiatan nyata menjadi sesuatu yang abstrak dengan bantuan gambar (pictorial). Ketika guru mengajarkan materi perbandingan sudut, kegiatan yang dapat dilakukan guru adalah melakukan demonstrasi seperti upacara bendera, mengamati tinggi pohon, serta mengamati lukisan di dinding. Setelah itu guru menuntun siswa (scaffolding) untuk menggambar kejadian yang tersebut. Langkah terakhir adalah guru meminta siswa untuk menyelesaikan permasalah hubungan sudut pada trigonometri.

Penelitian mengenai pendekatan CPA telah banyak dilakukan antara lain untuk meningkatkan hasil belajar (Ramadhan, 2012), meningkatkan kemampuan spasial (Mahayukti et al., 2019), pemahaman konsep matematika (Agrawal \& Morin, 2016; Milton, Flores, Moore, Taylor, \& Burton, 2018; Varma \& Schwartz, 2011) serta sikap dan performa siswa (Salingay \& Tan, 2018). Penerapan pendekatan CPA juga sudah pernah dilakukan untuk meningkatkan kemampuan representasi matematis antara lain pada materi matematika tingkat SD (Putri, 2015), namun sejauh ini belum ditemukan penerapan pendekatan CPA untuk meningkatkan kemampampuan representasi matematis pada materi trigonometri. Pada penelitian ini, bertujuan mengetahui pengaruh penerapan pendekatan CPA terhadap kemampuan representasi matematis siswa pada materi trigonometri dengan berbantuan Lembar Kerja Peserta Didik (LKPD).

\section{METODE PENELITIAN}

Penelitian eksperimen semu ini menggunakan desain penelitian pretestpost test control group design. Populasi dari penelitian ini adalah seluruh siswa kelas X MAN 2 Bekasi yang terdiri dari 4 kelas dengan jumlah siswa sebanyak 160 orang. Teknik pengambilan sampel yang digunakan adalah cluster sampling. Cluster sampling merupakan teknik survei yang umum dilakukan dengan mengambil sampel secara acak namun pengambilan acak sampel tidak dilakukan secara individu namun berdasarkan kelompok responden (Dorofeev \& Grant, 2006). Dari 4 kelas yang tersedia, maka dipilih kelas X IPA 1 menjadi kelas 
eksperimen untuk diterapkan pendekatan Concrete-Pictorial-Abstract (CPA) dalam pembelajarannya dan X IPA 3 menjadi kelas kontrol yang diterapkan pembelajaran konvensional.

Test kemampuan representasi matematis diberikan dalam dua tahap yaitu pretest dan posttest. Pretest diberikan untuk mengetahui kemampuan awal dari siswa sebelum dilakukan tindakan, sedangkan pemberian post test dilakukan setelah adanya penerapan pendekatan CPA. Post test bertujuan untuk melihat pengaruh penerapan pendekatan CPA terhadap kemampuan representasi matematis. Desain penelitian pretest-post test control group design dapat dilihat pada Tabel 1.

Tabel 1. Desain Penelitian

\begin{tabular}{ccc}
\hline Pretest & Perlakuan & Post test \\
\hline $\mathrm{O} 1$ & $\mathrm{X}$ & $\mathrm{O} 2$ \\
$\mathrm{O} 3$ & & $\mathrm{O} 4$ \\
\hline
\end{tabular}

Keterangan:

O1 : Hasil Pretest kelas eksperimen

O2 : Hasil Post test kelas eksperimen

O3 : Hasil Pretest kelas kontrol

O4 : Hasil Post test kelas kontrol

$\mathrm{X}$ : Pendekatan CPA

Pengumpulan data pada penelitian ini dilakukan dengan cara memberikan tes kemampuan representasi matematis yang terdiri dari 6 soal yang berbentuk uraian. Setelah data diperoleh, maka data akan diuji normalitas menggunakan uji Kolmogorov-Smirnov, homogenitas menggunakan uji F serta pengaruh penerapan pendekatan CPA terhadap kemampuan representasi matematis menggunakan uji beda N-Gain ternormalisasi. Untuk melihat peningkatan kemampuan representasi matematis maka data diuji menggunakan N-Gain ternormalisasi (Hake, 1999).

\section{HASIL PENELITIAN DAN PEMBAHASAN}

Tujuan dari data penelitian ini adalah untuk menjawab pertanyaan apakah kemampuan representasi matematika siswa yang diberikan pendekatan CPA lebih 
baik dibandingkan siswa yang mengikuti pembelajaran secara konvensional. Berikut akan disajikan hasil analisis data untuk menjawab pertanyaan tersebut.

Sebelum pelaksanaan pembelajaran menggunakan pendekatan CPA, siswa diberikan soal pretest berbentuk soal uraian yang mengandung indikator representasi matematis. Pretest ini dilakukan dengan tujuan untuk menguji normalitas dan homogenitas dari sampel penelitian. Uji normalitas data sampel penelitian menggunkan uji Kolmogorov-Smirnov dan Saphiro-Wilk. Adapun hasil uji normalitas pretest dari sampel penelitian dapat dilihat pada Tabel 2.

Tabel 2. Hasil Uji Normalitas Pre Test

\begin{tabular}{ccccccc}
\hline \multirow{2}{*}{ Kelas } & \multicolumn{3}{c}{ Kolmogorov-Smirnov } & \multicolumn{3}{c}{ Shapiro-Wilk } \\
& Statistic & df & Sig. & Statistic & df & Sig. \\
\hline X IPA 1 & .119 & 39 & .180 & .946 & 39 & .059 \\
X IPA 3 & .125 & 39 & .125 & .950 & 39 & .082 \\
\hline
\end{tabular}

Berdasarkan hasil uji normalitas pretest pada Tabel 2 dapat terlihat bahwa nilai sig. hitung > sig. tabel $(0,05)$. Hal ini berarti bahwa hasil pretest sampel penelitian berdistribusi normal. Langkah berikutnya adalah menguji homogenitas dari sampel penelitian. Adapun hasil uji homogenitas pretest dari sampel penelitian dapat dilihat pada Tabel 3.

Tabel 3. Hasil Uji Homogenitas Pre Test

\begin{tabular}{cccc}
\hline Levene Statistic & df1 & df2 & Sig. \\
\hline 3.779 & 1 & 78 & .055 \\
\hline
\end{tabular}

Berdasarkan hasil uji homogenitas pada Tabel 3, dapat dilihat bahwa sig. hitung > sig. tabel $(0,05)$. Hal ini menunjukkan bahwa hasil pretest siswa homogen.Ini berarti bahwa kemampuan awal dari sampel penelitian sama sebelum dilakukannya penerapan pendekatan CPA di kelas eksperimen. Setelah melakukan pretest dan diperoleh bahwa hasil tes berdistribusi normal dan homogeny maka langkah berikutnya adalah menerapkan pendekatan CPA di kelas eksperimen.

Setelah penerapan pendekatan CPA selesai, langkah berikutnya adalah melakukan posttest mengenai kemampuan representasi matematis. Adapun uji yang dilakukan pada hasil post test adalah uji homogenitas dan uji beda N-Gain 
ternormalisasi. Uji homogenitas pada post test bertujuan untuk melihat apakah terdapat perbedaan kemampuan representasi matematis antara kelas kontrol yang menerapkan pendekatan konvensional dan kelas eksperimen yang menerapkan pendekatan CPA. Hasil uji homogenitas posttest sampel penelitian dapat dilihat pada Tabel 4 .

Tabel 4.Uji Homogenitas Post Test

\begin{tabular}{cccc}
\hline Levene Statistic & df1 & df2 & Sig. \\
\hline 6.249 & 1 & 78 & .015 \\
\hline
\end{tabular}

Hasil uji homogenitas pada Tabel 4 menunjukkan bahwa nilai sig. hitung $(0,015)<$ sig. tabel $(0,05)$. Hal ini menujukkan bahwa terdapat perbedaan kemampuan representasi matematis antara kelas yang diajar dengan pendekatan CPA dengan kelas yang diajar dengan pendekatan konvesional. Langkah berikutnya adalah melakukan uji beda N-Gain ternormalisasi.

Uji beda N-Gain ternormalisasi bertujuan untuk melihat pengaruh penerapan pendekatan CPA di kelas eksperimen dibandingkan dengan kelas kontrol yang menerapkan pendekatan konvensional. Hasil uji beda N-Gain ternormalisasi dapat dilihat pada Tabel 5.

Tabel 5. Hasil Uji Beda N-Gain Ternormalisasi

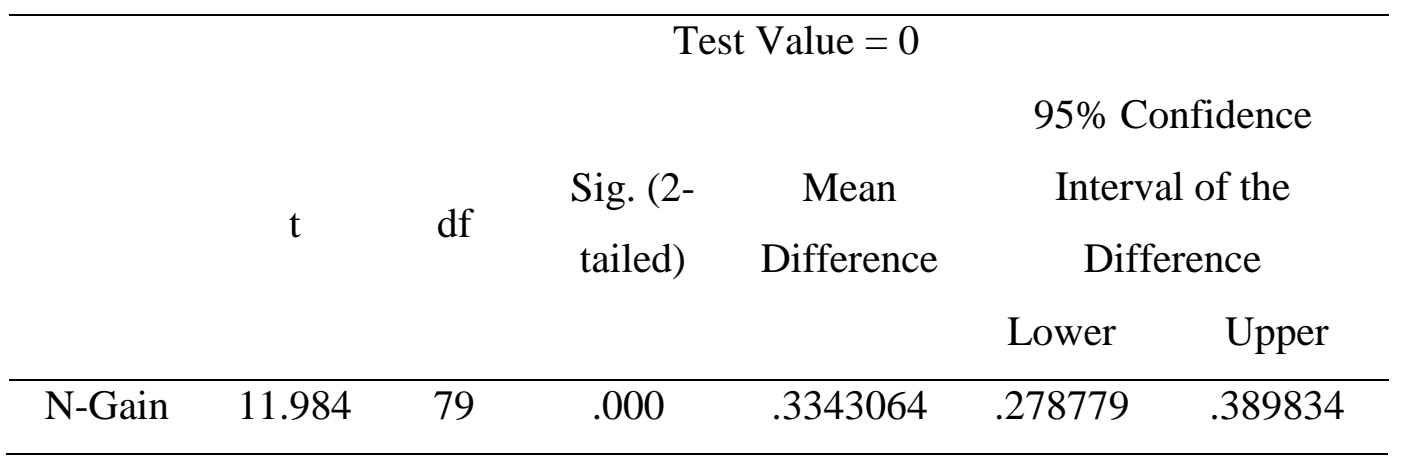

Berdasarkan hasil uji pada Tabel 5 dapat dilihat bahwa nilai sig. hitung < sig. tabel $(0,05)$, artinya terdapat pengaruh penerapan pendekekatan CPA terhadap kemampuan representasi matematis siswa yang diajar menggunakan pendekatan CPA.

Pelaksanaan pendekatan CPA di dalam kelas eksperimen dilakukan dengan tiga tahap yaitu Concrete-Pictorical-Abstract. Pada tahap concrete, 
peneliti mengenalkan benda nyata yang mengesankan pada siswa yang akan digunakan dalam menyelesaikan permasalahan matematika. Pada kegiatan ini peneliti menggunakan kegiatan upacara bendera sebagai alat untuk menjelasakan hubungan antara sisi tegak, sisi datar dan hipotenusa. Pada tahap pictorial, peneliti mulai menggambarkan sebuah bentuk segitiga yang merepresentasikan antara sisi tegak, sisi datar, dan hipotenusa. Kemudian peneliti mulai menjelaskan hubungan sisi tegak, sisi datar, dan hipotenusa dalam segitiga serta memberikan simbol terhadap hubungan antara sisi-sisi segitiga dalam trigonometri. Pada tahap abstract, peneliti memberikan permasalahan trigonometri yang berhubungan dengan simbol-simbol yang telah diberikan pada tahap sebelumnya.

Pendekatan CPA mampu memberikan pengaruh positif terhadap kemampuan representasi matematika disebabkan karena dalam pendekatan CPA lebih menuntut siswa untuk menguasai teknik menyelesaikan permasalahan matematika dari pada hanya mencari jawaban dari permasalahan matematika. Penerapan pendekatan CPA di dalam kelas menggunakan bantuan Lembar Kerja Peserta Didik (LKPD). LKPD berisi kegiatan siswa memanipulasi benda nyata secara berkelompok. Kegiatan diskusi yang dilakukan juga bertujuan agar setiap siswa dapat memahami serta memberikan pendapat terhadap ide-ide yang disampaikan dalam kelompok. Selain itu, guru juga membebaskan siswa untuk melakukan kegiatan di luar kelas yang memiliki hubungan dengan hubungan sudut pada trigonometri, seperti melakukan pengamatan terhadap tiang bendera dan pohon.

Pendekatan CPA sangat efektif dalam membantu siswa menyelesaikan kesulitan matematika, karena pendekatan CPA dilakukan secara bertahap diawali dengan pengenalan objek yang sebenarnya melalui gambar menuju simbol matematika yang abstrak (Sousa, 2008). Selain itu, penerapan CPA di dalam kelas ekseperimen juga terbukti mampu untuk meningkatkan kemampuan terhadap konsep trigonometri, kemampuan spasial matematika dan hasil belajar matematika (Mahayukti et al., 2019; Milton et al., 2018; Putri, 2015). 


\section{SIMPULAN}

Berdasarkan hasil penelitian dapat disimpulkan bahwa kemampuan representasi matematis siswa yang diajarkan dengan pendekatan CPA lebih baik dibandingkan siswa yang diajarkan dengan pembelajaran konvesional. Hal ini disebabkan karena pendekatan CPA memiliki tahapan-tahapan yang membentuk proses berpikir siswa untuk menguasai teknik pemecahan masalah matematika. Tahapan-tahapan tersebut terdiri dari: tahap concrete terjadi ketika siswa mampu memanipulasi suatu benda atau pengalaman yang dapat dijadikan sebagai sumber pembelajaran trigonometri seperti penggaris segitiga dan kegiatan upacara bendera, tahap pictorial merupakan tahapan dimana siswa dituntut mampu menggunakan representasi berupa gambar, tabel, diagram dalam menafsirkan permasalahan matematika dan diakhiri dengan tahap abstract dimana siswa dituntut mampu menuliskan representasi simbol yang menunjukkan pemahaman siswa terhadap permasalahan matematika. Hasil penelitian ini diharapkan dapat dijadikan suatu alternatif yang digunakan oleh guru dalam meningkatkan kemampuan matematika, khususnya kemampuan representasi matematis. Penelitian ini masih menggunakan kegiatan sederhana dalam memberikan contoh peran matematika dalam kehidupan sehari-hari serta penggunaan LKPD yang berisi materi trigonometri dan langkah-langkah pengenalan simbol trigonometri. Penelitian kedepan diharapkan peneliti lain mampu menggunakan pendekatan CPA melalui media pembelajaran berbasis teknologi dalam memperkenalkan matematika dalam kehidupan sehari-hari.

\section{DAFTAR PUSTAKA}

Agrawal, J., \& Morin, L. L. (2016). Evidence-based practices: applications of concrete representational abstract framework across math concepts for students with mathematics disabilities. Learning Disabilities Research and Practice, 31(1), 34-44. https://doi.org/10.1111/ldrp.12093

Astuti, E. P. (2017). Representasi matematis mahasiswa calon guru dalam menyelesaikan masalah matematika. Beta Jurnal Tadris Matematika, 10(1), 70. https://doi.org/10.20414/betajtm.v10i1.100

Batchelor, S., Keeble, S., \& Gilmore, C. (2015). Magnitude representations and counting skills in preschool children. Mathematical Thinking and Learning, 17(2-3), 116-135. https://doi.org/10.1080/10986065.2015.1016811

Bouck, E., Park, J., \& Nickell, B. (2017). Using the concrete-representationalabstract approach to support students with intellectual disability to solve change-making problems. Research in Developmental Disabilities, 60, 24- 
36. https://doi.org/10.1016/j.ridd.2016.11.006

Brijlall, D., \& Niranjan, C. (2015). Using manipulatives to support an embodied approach to learning trigonometry in a south african school: a case study. Africa Education Review, 12(3), 361-380. https://doi.org/10.1080/18146627.2015.1110893

Dewolf, T., Van Dooren, W., \& Verschaffel, L. (2017). Can visual aids in representational illustrations help pupils to solve mathematical word problems more realistically? European Journal of Psychology of Education, 32(3), 335-351. https://doi.org/10.1007/s10212-016-0308-7

Dündar, S. (2015). The relationships among pre-service mathematics teachers' beliefs about mathematics, mathematics teaching, and use of technology in China. Eurasia Journal of Mathematics, Science and Technology Education, 11(6), 1363-1378. https://doi.org/10.12973/eurasia.2015.1396a

Gerhana, M. T. C., Mardiyana, M., \& Pramudya, I. (2017). The Effectiveness of project based learning in trigonometry. Journal of Physics: Conference Series, 895(1), 0-6. https://doi.org/10.1088/1742-6596/895/1/012027

Gür, H. (2009). Trigonometry learning. New Horizons in Education, 57(1), 67-80.

Kalathil, R. R., \& Sherin, M. G. (2000). Role of students' representations in the mathematics classroom. Fourth International Conference of the Learning Sciences, 27-28.

Kamber, D., \& Takaci, D. (2018). On problematic aspects in learning trigonometry. International Journal of Mathematical Education in Science and Technology, 49(2), 161-175. https://doi.org/10.1080/0020739X.2017.1357846

Mahayukti, G. A., Dianawati, N. P. S., Ardana, I. M., \& Suryawan, I. P. P. (2019). The effect of concrete-pictorial-abstract learning strategy on spatial sense ability. Journal of Physics: Conference Series, 1317(1). https://doi.org/10.1088/1742-6596/1317/1/012007

Maor, E. (2013). Trigonometric delights. Princenton, New Jersey: Princeton University Press.

Mesa, V., \& Herbst, P. (2011). Designing representations of trigonometry instruction to study the rationality of community college teaching. ZDM International Journal on Mathematics Education, 43(1), 41-52. https://doi.org/10.1007/s11858-010-0300-7

Milton, J. H., Flores, M. M., Moore, A. J., Taylor, J. L. J., \& Burton, M. E. (2018). Using the concrete - representational - abstract sequence to teach conceptual understanding of basic multiplication and division. Learning Disability Quarterly, 1-14. https://doi.org/10.1177/0731948718790089

NCTM. (2000). Principles Standards and Standards for School Mathematics. Reston: VA: National Council of Teachers of Mathematics.

Price, C., \& Van Jaarsveld, P. (2017). Using open-response tasks to reveal the conceptual understanding of learners-learners teaching the teacher what they know about trigonometry. African Journal of Research in Mathematics, Science and Technology Education, 21(2), 159-175. https://doi.org/10.1080/18117295.2017.1329054

Putri, H. E. (2015). The influence of Concrete Pictorial Abstract (CPA) approach to the Mathematical representation ability achievement of the pre-service teachers at elementary school. International Journal of Education and 
Research, 3(6), 113-126.

Ramadhan, N. A. (2012). Penerapan pendekatan Concrete Pictorial Abstract (CPA) Bilangan cacah untuk meningkatkan hasil belajar matematika pada anak tunagrahita ringan kelas 6 di SD. Jassi Anakku, 11(2), 115-124.

Rosengrant, D., Etkina, E., \& Van Heuvelen, A. (2007). An overview of recent research on multiple representations. AIP Conference Proceedings, 883, 149-152. https://doi.org/10.1063/1.2508714

Sahendra, A., Budiarto, M. T., \& Fuad, Y. (2018). Students' representation in mathematical word problem-solving: exploring students' self-efficacy. Journal of Physics: Conference Series, 947(1), 1-5. https://doi.org/10.1088/1742-6596/947/1/012059

Salingay, N. R. R., \& Tan, D. A. (2018). Concrete-pictorial-abstract approach on students' attitude and performance in mathematics. International Journal of Scientific and Technology Research, 7(5), 90-111.

Sarkam, S., Sujadi, I., \& Subanti, S. (2019). Mathematical connections ability in solving trigonometry problems based on logical-mathematical intelligence level. Journal of Physics: Conference Series, 1188(1). https://doi.org/10.1088/1742-6596/1188/1/012022

Solikin, A. (2016). Aplikasi aturan cosinus dan sinus segitiga bola dalam perhitungan arah kiblat (sebuah relasi antara matematika dan agama). MUST: Journal of Mathematics Education, Science and Technology, 1(2), 164. https://doi.org/10.30651/must.v1i2.235

Sousa, D. A. (2008). How the brain learns mathematics. Thousand Oaks, California: Corwin Press.

Varma, S., \& Schwartz, D. L. (2011). The mental representation of integers: An abstract-to-concrete shift in the understanding of mathematical concepts. Cognition, 121(3), 363-385. https://doi.org/10.1016/j.cognition.2011.08.005

Wahyu, K., Amin, S. M., \& Lukito, A. (2017). Motivation cards to support students' understanding on fraction division. International Journal on Emerging Mathematics $\quad$ Education, $\quad 1(1), \quad 99$. https://doi.org/10.12928/ijeme.v1i1.5760

Walsh, R., Fitzmaurice, O., \& O'Donoghue, J. (2017). What subject matter knowledge do second-level teachers need to know to teach trigonometry? An exploration and case study. Irish Educational Studies, 36(3), 273-306. https://doi.org/10.1080/03323315.2017.1327361

Whitin, P. E. (2007). The Mathematics Survey: A Tool for assessing attitudes and dispositions. Teaching Children Mathematics, 13(8), 426-433. 